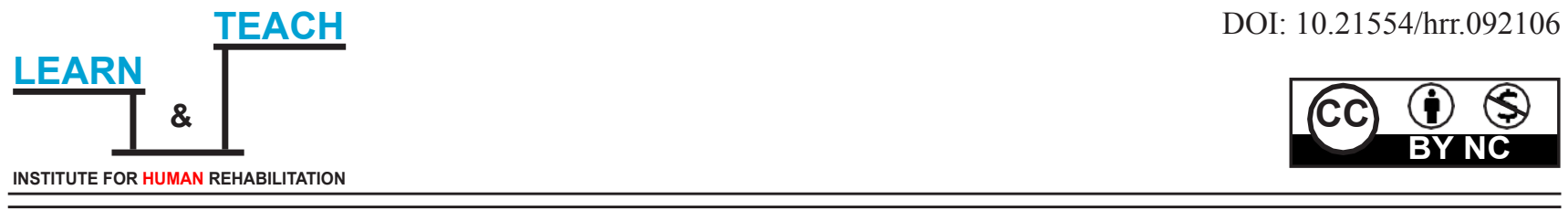

\title{
METACOGNITION AND ENGLISH READING-RELATED OUTCOMES FOR D/DEAF AND HARD OF HEARING STUDENTS: A NARRATIVE REVIEW
}

\author{
Peixuan Yan ${ }^{1}$, Peter V. Paul ${ }^{2}$ \\ ${ }^{1}$ Earlham College \\ ${ }^{2}$ Department of Educational Studies, The Ohio State University
}

Received: $2021 / 7 / 14$

Accepted: 2021/9/18

\begin{abstract}
The purpose of this narrative review was to summarize empirical studies regarding the effects of metacognition on English reading-related outcomes for students who are d/Deaf and hard of hearing (d/Dhh). This review covered the timeframe from the publication of the previous and only narrative review conducted by Strassman (1997) to 2020. Several of Strassman's assertions were confirmed, including the oft-repeated one: d/Dhh students possess inadequate comprehension-monitoring skills. In fact, the students are not aware of effective metacognitive strategies and, in general, do not know "what they do not know." Although intervention is strongly recommended, a few later studies asserted that such intervention not only should be based on the recommendations of the National Reading Panel, but also should be differentiated to meet the individual needs of d/Dhh students. It was argued that d/Dhh reading comprehension challenges are due to metacognitive or executive function issues; however, this assumption needs to be contextualized within a framework of reading which entails decoding and comprehension processes.
\end{abstract}

Keywords: d/Deaf and hard of hearing; metacognition; English reading comprehension

The development of reading comprehension skills continues to be a challenge for a number of students who are $\mathrm{d} /$ Deaf and hard of hearing (d/Dhh). Much of the literature review has documented the reading comprehension levels of students with prelingual (prior to age 3) severe to profound hearing loss albeit some students with prelingual moderate losses have been included in the analyses. Many 18-to-19 year old students graduate high school $\left(12^{\text {th }}\right.$ grade in the USA) reading on a level that is commensurate with the average 8-to-9-year-old typical literacy (also hearing) student at the $3^{\text {rd }}$ or $4^{\text {th }}$ grade (Allen, 1986; Paul et al., 2013; Qi \& Mitchell, 2012; Trezek et al., 2011).

A few critical reasons for the $3^{\text {rd }}$ or $4^{\text {th }}$-grade reading-level plateau are the increase of inferential (e.g., answering high-level questions; summarizing; drawing conclusions, etc.), complex language (e.g., vocabulary and syntax), and knowledge (e.g., concepts; prior knowledge) demands associated with reading materials beyond the third grade (e.g., see Mayer \& Trezek, 2015; Paul et al., 2013; Trezek et al., 2011). These demands place an enormous burden on students who might be about one or two reading grade levels behind by the time they enter the third grade. In the upper elementary grades $\left(4^{\text {th }}, 5^{\text {th }}, 6^{\text {th }}\right.$ intheUSA $)$, there is a tremendous increase in the use of decontextualized or literate language (e.g., specialized vocabulary, concepts) in print texts. This increase, coupled with an inadequate command of the English language, often contributes to a widening of the achievement gap between $\mathrm{d} /$ Dhh students and typical literacy learners throughout the middle ( $7^{\text {th }}$, $8^{\text {th }}$ grade) and high school years ( $9^{\text {th }}$ through $12^{\text {th }}$ grade). 
There is some evidence that reading comprehension scores might be improving due to early intervention and early amplification and to the advent of digital assistive technology such as hearing aids and cochlear implantation (Archbold, 2010; Easterbrooks \& Beal-Alvarez, 2012; Mayer \& Leigh, 2010; Mayer \& Trezek, 2018). It should be kept in mind that estimates of the reading level are inconsistent and should be considered "gross averages" due to the uneven progress of cohorts of d/Dhh children. That is, some children are reading at or above grade level whereas others are reading below grade level. This situation might be due to the difficulty of measuring reading achievement, artifacts of the tests, inadequate research designs, incomplete documentation of demography and achievement data, or other factors, which have yet to be delineated (Moores, 2001; Paul, 2009). Nevertheless, there are persistent reading difficulties for a number of students, particularly those with hearing losses from moderate to profound.

With respect to extant reading theories (e.g., those based on the USA National Reading Panel's recommendations [2000], interactive social-cognitive models [see Alvermann, Unrau, \& Ruddell, 2013; Connor et al., 2014]; and selfregulation models [e.g., Pintrich, 2000]), there are several factors that contribute to the English reading difficulties of $d /$ Deaf and hard of hearing students. These factors include inadequate development of the through-the-air use of the English language (i.e., receptive and expressive skills), decoding skills (e.g., word identification), and comprehension skills (e.g., use of prior knowledge, metacognition, inferencing skills). Other critical issues include sociocultural factors (e.g., home environment, teacher-student relations, etc.) and affective factors (e.g., motivation, interest, etc. of readers). In addition, attention should be paid to the effects of the contents of the reading curriculum, teacher preparation practices, parental involvement and the home environment, and cultural instructional practices (i.e., reading instructional practices within a specific culture or geographical region).

Our understanding of these factors has also been guided by a framework labeled the qualitative similarity hypothesis (QSH; Paul et al., 2013). The QSH asserts that $\mathrm{d} / \mathrm{Dhh}$ students have a reading developmental trajectory that is similar to that of typical literacy learners with respect to English as a first or second language. Specifically, the QSH asserts that $\mathrm{d} / \mathrm{Dhh}$ students proceed through similar developmental stages, produce roughly the same errors, and use similar beneficial reading strategies compared to typical literacy learners (Paul et al., 2013). Moreover, the QSH states that the reading curriculum should be roughly the same for both $\mathrm{d} /$ Dhh students and typical literacy learners, regardless of individual differences. The QSH also argues, however, that typical reading instruction should be combined with alternative approaches and should be differentiated to promote positive learning outcomes.
This is especially important for $\mathrm{d} / \mathrm{Dhh}$ literacy learners who are struggling with the development of adequate literacy skills and who may experience difficulty with using strategies that are effective for typical literacy (hearing) learners.

The focus of this qualitative narrative review is on metacognition, which plays a role in the development and use of effective comprehension strategies recommended, for example, by the National Reading Panel (2000). Metacognition is described as knowing about knowing and knowing how to know (Brown, 1975); that is, it involves "knowledge about cognition and regulation of cognition" (Baker \& Brown, 1984, p. 353). In reading, metacognitive knowledge refers to knowledge about oneself as a reader as well as knowledge about a range of topics, languageboth primary (speaking and/or signing) and secondary (i.e., written language) - text structures, literacy tasks, and even teachers' expectations and literacy instructional styles.

It is possible to categorize metacognition into two broad areas: metacognitive knowledge/awareness and metacognitive control (Baker \& Beall, 2009). The knowledge aspect of metacognition overlaps with the prior knowledge domain whereas the control aspect entails self-regulatory or monitoring strategies that literacy learners utilize before, during, and after reading/ literacy tasks. One of the most important effective metacognitive strategies, according to the National Reading Panel, is comprehension monitoring, which refers to the ability to comprehend (i.e., knowing that it has occurred) and the ability to use an appropriate strategy to "repair" comprehension breakdowns or problems. The monitoring of one's comprehension is driven by metacognitive knowledge and strategies, and explicit instruction in comprehension monitoring (and other comprehension strategies) has been strongly recommended for $\mathrm{d} /$ Deaf and hard of hearing literacy learners (e.g., see reviews in Luckner \& Handley, 2008; Trezek et al., 2011). As is discussed later, the use of metacognition is part of the executive function (e.g., see discussion in Marschark \& Knoors, 2012).

A number of $\mathrm{d} /$ Deaf and hard of hearing children and adolescents have difficulty engaging in cognitive tasks such as summarizing, drawing conclusions, or making inferences during reading (Kyle \& Cain, 2015; Trezek et al., 2011). There is some research showing that, if students lack prior knowledge or struggle with print decoding skills, the teaching and use of metacognitive strategies may still be beneficial-albeit this might not completely overcome other difficulties associated with the task of reading (e.g., Brigham et al., 2007; also, see related discussions in Baker \& Beall, 2009; Massey, 2009).

To become critical readers, it has been asserted that students need, at least, to obtain and apply an adequate prior knowledge of the contents and specialized vocabulary associated with academic disciplines (e.g., reading, social studies, science). Developing and using this storehouse of prior knowledge is purported to facilitate the ability to think, explore, and engage in classroom discussions. 
Students also need a general understanding of the metalanguage of topics associated with the larger mainstream culture of society, often labeled cultural literacy (Hirsch, Kett, \& Trefil, 2002). The use of a metalanguage and the application of prior knowledge are affected by the level of language proficiency or competency, including vocabulary knowledge (e.g., Marschark \& Knoors, 2012; Paul \& Wang, 2012: Paul et al., 2013).

To the best of our knowledge, the previous and only narrative review, focusing exclusively on metacognition and deafness, was conducted by Strassman (1997). Because of the strong positive relationship between metacognitive skills and reading comprehension, at least for typical literacy readers, it is important to synthesize the empirical research since the work of Strassman. The focus of our review is on the effects of metacognition on English reading-related outcomes. We acknowledge that there have been other areas of metacognitive research (e.g., the use of specific metacognitive strategies and metacognitive assessments); however, we are mainly interested in the effects on English reading-related outcomes (e.g., vocabulary knowledge, reading comprehension, etc.) for $\mathrm{d} /$ Deaf and hard of hearing students.

In essence, the purpose of the present review was to explore the effects of metacognition on English reading-related outcomes for $\mathrm{d} /$ Deaf and hard of hearing students. After summarizing the work of Strassman (1997) to provide a context, we investigate primary (original) research studies involving students at the elementary and middle school levels (grades 1-8), and at the secondary (grades 9-12) and postsecondary levels (i.e., post high school in the USA).

The main research question was as follows: What are the general findings of the effects of metacognition for English reading-relatedoutcomes? We explore and discuss the nature of the approaches researchers employed to examine the effects of metacognition. English reading-related variables include items such as the effects on reading comprehension per se, vocabulary knowledge, ability to answer questions, and others that impact the comprehension of print.

\section{METHOD}

The present review utilized a qualitative meta-analysis (i.e., narrative review) as the method for reviewing and synthesizing studies involving $\mathrm{d} /$ Deaf and hard of hearing literacy learners. Qualitative meta-analysis is a rigorous, systematic and narrative analysis of both primary and secondary research findings. The aim of a qualitative meta-analysis is to contribute to the theory's construction, description, and growth in order to provide a comprehensive understanding of a specific field of research (Wang \& Williams, 2014). In recent years, various approaches to this category of research analysis have been established under different labels such as qualitative meta-analysis, meta-synthesis, meta-ethnography, meta-method, meta-summary, meta-study, metatheory, and grounded formal theory (Timulak, 2007). In addition, qualitative meta-analysis has been applied to numerous fields such as education, sociology, anthropology and psychology.

The present review used Wang and Williams's method as the analysis model; that is, the data from both qualitative and quantitative empirical studies were subjected to a critical analysis. Typically, qualitative meta-analytic studies only analyze and synthesize qualitative studies. This includes only a rigorous narrative analysis of the components of primary research (e.g., methodology, findings). Nonetheless, the research studies cited in the present review have used different methodologies, including qualitative, quantitative, and mixed approaches. Wang and Williams (2014) provided a model for a qualitative meta-analysis, which includes both qualitative and quantitative studies. To be precise, these authors performed a critical analysis of existing meta-analyses, both qualitative and quantitative, on reading research with $\mathrm{d} /$ Deaf and hard of hearing students. We performed a review of only empirical, original research investigations involving metacognition, reading, and deafness.

\section{Search Procedures}

In the present review, the procedures for the literature search consisted mainly of two phases: the use of an electronic database via inputting keywords (and combinations) such as "d/Deaf and hard of hearing", "deaf", "hard of hearing", "hearing impaired" "hearing impairment", "metacognition", "prior knowledge", and "English reading comprehension," and hand searches with suitable references. The keywords were not restricted to titles and abstracts; all potentially applicable studies were perused and evaluated.

Two literature search strategies were used to locate relevant studies. First, the electronic search engine EBSCOhost was used with specific databases including:

- Academic Search Premier

- Academic Search Complete

- Education Search Complete

- ERIC

- PsycINFO

Furthermore, the electronic search also included the following journals to identify all appropriate publications. The selection of specific journals were:

- American Annals of the Deaf

- Deafness \& Education International

- The Volta Review

- The Journal of Deaf Studies and Deaf Education

After inputting keywords and setting selection criteria (discussed below), a total of 11 primary empirical articles met the selection criteria. A $12^{\text {th }}$ empirical article was also selected; however, the participants were non-English speaking (Arabic). Although this article did not meet our selection criteria, we included it as an exemplar due to the focus on an emerging trend - the use of digital literacy. 
With respect to our inclusion criteria, five of the 11 empirical articles were published in the American Annals of the Deaf; four articles were retrieved from the Journal of Deaf Studies and Deaf Education. Two articles were published in the European Journal of Special Needs Education.

To ensure the integrity of the literature search, a manual search was conducted after the electronic search. In the manual search, each study's reference list was examined in order to avoid or minimize missing potential studies in the electronic search. As mentioned, we also included a narrative review by Strassman (1997) because the focus of our paper was to review research studies on metacognition and reading conducted since the Strassman's review.

\section{Selection Criteria}

The present investigation aimed to understand the effects of metacognition on English reading-related outcomes for $\mathrm{d} /$ Deaf and hard of hearing students. The selection criteria for studies published between 1997 (Strassman's date) and 2020 were as follows: (1) qualitative, quantitative, or combined method primary research studies published in peer-reviewed journals; (2) studies involved participants from Grade 1 to postsecondary or post high-school stages; and (3) studies were related to metacognition and English reading comprehension or English reading-related outcomes. After describing and synthesizing the studies, we documented information on research purpose or research questions, methodology, participants, English-reading outcomes, and implications.

\section{Excluded Studies}

Ten published studies were excluded from this narrative meta-analysis because they did not report English reading-related outcomes. For example, Courtin and Melot (2005) explored students' metacognitive development though appearance-reality and false belief tasks. Yuknis (2014) examined the revising processes used by middle school students as they composed essays in English classes. Franklin et al. (2018) investigated metacognitive strategies-based retention program among first generation STEM students. Another study focused on the effects of assistive technology and sign language interpreting and reading skills acquisition for deafblind adults (Ingraham \& Andrews, 2010).

Furthermore, several studies that examined the effects of metacognition on Arabic reading outcomes were excluded (Alasim, 2020 [prior knowledge]; AlHilawani, 2000, 2001, 2008, 2017). However, we did review one study (Alsalem, 2018) because of the innovative focus on digital literacy. Finally, we excluded one comparative study, which examined the impact of cognitive strategy-based instruction on learners in the United Kingdom and China (Martin et al., 2001).

\section{Included Studies}

The list of 11 primary research studies (involving English reading outcomes) was categorized into two broad groups: Elementary and Middle School (i.e., up to the $8^{\text {th }}$ grade; 7 to 13 years old) and Secondary and Postsecondary ( $9^{\text {th }}$ grade and beyond; 16 years and older). As mentioned previously, we included the narrative review by Strassman (1997), which appeared in the Journal of Deaf Studies and Deaf Education, and an empirical article on digital literacy (Alsalem, 2018) as an exemplar. The selected 11 empirical studies, the Strassman (1997) article, and the digital literacy article (Alsalem, 2018) are shown below in Table 1 . 
Table 1. Reference List of Selected Studies

\section{Elementary and Middle School Age Group (7 to 13 Years)}

Aceti, K. J., \& Wang, Y. (2010). The teaching and learning of multimeaning words within a metacognitively based curriculum. American Annals of the Deaf, 155(2), 118-123.

Benedict, K. M., Rivera, M. C., \& Antia, S. D. (2015). Instruction in metacognitive strategies to increase deaf and hard of hearing students' reading comprehension. Journal of Deaf Studies and Deaf Education, 20(1), 1-15.

Brigham, M., \& Hartman, M. C. (2010). What is your prediction? Teaching the metacognitive skill of prediction to a class of sixth and seventh grade students who are deaf. American Annals of the Deaf, 155(2), 137-143.

Schirmer, B. R. (2003). Using verbal protocols to identify the reading strategies of students who are deaf. Journal of Deaf Studies and Deaf Education, 8(2), 157-70.

Schirmer, B. R., Bailey, J., \& Lockman, A. S. (2004). What verbal protocols reveal about the reading strategies of deaf students: A replication study. American Annals of the Deaf, 149(1), 5-16.

\section{Secondary and Post-Secondary Age Group (16 Years and Older)}

Banner A., \& Wang, Y. (2010). An analysis of the reading strategies used by adult and student deaf readers. Journal of Deaf Studies and Deaf Education, 16(1), 2-23.

Borgna, G., Convertino, C., Marschark, M., Morrison, C., \& Rizzolo, K. (2011). Enhancing deaf students' learning from sign language and text: Metacognition, modality, and the effectiveness of content scaffolding. Journal of Deaf Studies and Deaf Education, 16(1), 79-100.

Kelly, R. R., Albertini, J. A., \& Shannon, N. B. (2001). Deaf college students' reading comprehension and strategy use. American Annals of the Deaf, 146(5), 385-400.

Morrison, C., Marschark, M., Sarchet, T., Convertino, C. M., Borgna, G., \& Dirmyer, R. (2013). Deaf students' metacognitive awareness during language comprehension. European Journal of Special Needs Education, 28(1), 78-90.

Walton, D., Borgna, G., Marschark, M., Crowe, K., \& Trussell, J. (2019). I am not unskilled and unaware: Deaf and hearing learners' self-assessments of linguistic and nonlinguistic skills. European Journal of Special Needs Education, 34(1), 20-34.

Wang, Y., Silvestri, J. A., \& Jahromi, L. B. (2018). Selected factors in reading comprehension for deaf and hearing adults: Phonological skills and metacognition. American Annals of the Deaf, 162(5), 445-462.

\section{Other Studies}

Alsalem, M. A. (2018). Exploring metacognitive strategies utilizing digital books: Enhancing reading comprehension among deaf and hard of hearing students in Saudi Arabian higher education settings. Journal of Educational Computing Research, 56(5), 645-674.

Note: Arabic reading skills; selected due to focus on digital literacy.

Strassman, B. K. (1997). Metacognition and reading in children who are deaf: A review of the research. Journal of Deaf Studies \& Deaf Education, 2(3), 140-149.

Note: Provided a context for the present study.

\section{Data Analysis}

Each selected study was reviewed and coded for objective and transparent analysis of data. As mentioned previously, the codes included purpose or research questions, methodology, participants, English reading outcomes, and implications (see Table 2). 
Table 2. Summary of the 12 Reviewed Empirical Articles

\begin{tabular}{|c|c|c|c|c|c|}
\hline Author \& Date & $\begin{array}{c}\text { Research Questions/ } \\
\text { Purpose }\end{array}$ & Methods & Participants & $\begin{array}{c}\text { English Reading } \\
\text { Outcomes }\end{array}$ & Implications \\
\hline $\begin{array}{l}\text { Aceti \& Wang } \\
(2010)\end{array}$ & $\begin{array}{l}\text { What is the } \\
\text { effect of explicit, } \\
\text { metacognitively } \\
\text { based instruction in } \\
\text { multimeaning words on } \\
\text { deaf students' ability } \\
\text { to complete tasks in } \\
\text { two areas: (1) matching } \\
\text { multimeaning words } \\
\text { with their corresponding } \\
\text { pictures and (2) reading } \\
\text { sentences containing } \\
\text { multimeaning words? }\end{array}$ & $\begin{array}{l}\text { Pretest- } \\
\text { Posttest } \\
\text { Intervention } \\
\text { Design }\end{array}$ & $\begin{array}{l}4 \mathrm{~d} / \text { Dhh students } \\
\text { from } 11 \text { to } 13 \\
\text { years old, enrolled } \\
\text { in a mixed sixth } \\
\text { and seventh grade } \\
\text { self- contained } \\
\text { class. } \\
\text { Hearing thresholds } \\
\text { were not reported. }\end{array}$ & $\begin{array}{l}\text { Increase in } \\
\text { multimeaning } \\
\text { word vocabulary } \\
\text { and reading } \\
\text { comprehension in } \\
\text { general. }\end{array}$ & $\begin{array}{l}\text { Learning } \\
\text { multimeaning } \\
\text { word vocabulary } \\
\text { and an } \\
\text { improvement } \\
\text { in reading } \\
\text { comprehension } \\
\text { can be } \\
\text { facilitated by } \\
\text { metacognitively } \\
\text { based explicit } \\
\text { instruction. }\end{array}$ \\
\hline $\begin{array}{l}\text { Benedict et al. } \\
(2015)\end{array}$ & $\begin{array}{l}\text { Does the CC\&R } \\
\text { strategy influence } \\
\text { reading behavior of } \\
\text { deaf or hard of hearing } \\
\text { students? } \\
\text { Reading behavior } \\
\text { was defined as } \\
\text { observable strategic and } \\
\text { nonstrategic behaviors } \\
\text { in which student engage } \\
\text { during oral reading. } \\
\\
\text { Does CC\&R strategy } \\
\text { influence reading } \\
\text { comprehension of } \\
\text { deaf or hard of hearing } \\
\text { students? } \\
\text { Reading comprehension } \\
\text { was defined as the } \\
\text { number of details } \\
\text { students could retell in } \\
1 \text { minute following oral } \\
\text { reading. }\end{array}$ & $\begin{array}{l}\text { Single-case } \\
\text { Experimental } \\
\text { Design }\end{array}$ & $\begin{array}{l}3 \text { student- teacher } \\
\text { dyads from three } \\
\text { suburban public } \\
\text { school districts. } \\
\text { The three students, } \\
9.2 \text { to } 10.9 \text { years } \\
\text { old, had bilateral } \\
\text { hearing losses } \\
\text { from moderate to } \\
\text { the profound level. } \\
\text { Students were } \\
\text { enrolled in general } \\
\text { education classes } \\
\text { from grades } 4 \text { to } 8 . \\
\text { Three teachers } \\
\text { held master's } \\
\text { degrees and } \\
\text { state teaching } \\
\text { certifications. } \\
\text { All teachers had } \\
\text { extensive teaching } \\
\text { experience. }\end{array}$ & $\begin{array}{l}\text { Students were able to } \\
\text { learn a metacognitive } \\
\text { strategy that enabled } \\
\text { them to monitor their } \\
\text { understanding of } \\
\text { content-area text and } \\
\text { resolve problems with } \\
\text { comprehension when } \\
\text { they arose. }\end{array}$ & $\begin{array}{l}\text { Instruction in } \\
\text { metacognitive } \\
\text { strategies to } \\
\text { increase strategic } \\
\text { reading behavior } \\
\text { can be an effective } \\
\text { method, which can } \\
\text { improve reading } \\
\text { comprehension for } \\
\text { d/Deaf or hard of } \\
\text { hearing students. }\end{array}$ \\
\hline $\begin{array}{l}\text { Brigham } \\
\text { \& Hartman } \\
(2010)\end{array}$ & $\begin{array}{l}\text { To teach the } \\
\text { metacognitive skill of } \\
\text { prediction. } \\
\text { To integrate } \\
\text { metacognitive skill } \\
\text { building into the } \\
\text { sixth- and seventh- } \\
\text { grade social studies } \\
\text { curriculum. }\end{array}$ & $\begin{array}{l}\text { Qualitative } \\
\text { Action } \\
\text { Research } \\
\text { Design }\end{array}$ & $\begin{array}{l}5 \text { Hispanic d/ } \\
\text { Dhh students, } \\
\text { with severe to } \\
\text { profound losses, } \\
\text { of a combined } \\
\text { sixth and seventh } \\
\text { grade total } \\
\text { communication } \\
\text { class. } \\
\text { Four boys and one } \\
\text { girl, whose ages } \\
\text { range from } 12 \text { to } \\
13.5 \text { years. } \\
\text { One student had } \\
\text { minor cerebral } \\
\text { palsy, and one had } \\
\text { attention deficit } \\
\text { hyperactivity } \\
\text { disorder and } \\
\text { Goldenhar } \\
\text { syndrome. }\end{array}$ & $\begin{array}{l}\text { The results show } \\
\text { that all students } \\
\text { demonstrated some } \\
\text { understanding of the } \\
\text { concept of prediction } \\
\text { and exhibit some } \\
\text { ability to make } \\
\text { predictions. } \\
\text { Students were still } \\
\text { unable to explain } \\
\text { the reasons for their } \\
\text { predictions. }\end{array}$ & $\begin{array}{l}\text { Future researchers } \\
\text { should focus on } \\
\text { attempts to teach } \\
\text { students how } \\
\text { to explain their } \\
\text { thought processes } \\
\text { in developing a } \\
\text { prediction. }\end{array}$ \\
\hline
\end{tabular}


Table 2. Continued

\begin{tabular}{|c|c|c|c|c|c|}
\hline $\begin{array}{l}\text { Schirmer } \\
(2003)\end{array}$ & $\begin{array}{l}\text { Whether the think } \\
\text { aloud method can } \\
\text { be used to examine } \\
\text { students' reading } \\
\text { strategies during } \\
\text { reading activities. } \\
\text { Whether verbal reports } \\
\text { of deaf students } \\
\text { demonstrate similar } \\
\text { reading strategies } \\
\text { as the verbal reports } \\
\text { of typical hearing } \\
\text { students with high } \\
\text { reading skills. }\end{array}$ & $\begin{array}{l}\text { Qualitative } \\
\text { Design } \\
\text { (verbal } \\
\text { reports and } \\
\text { protocol } \\
\text { analysis) }\end{array}$ & $\begin{array}{l}10 \text { d/Dhh } \\
\text { elementary level } \\
\text { students enrolled } \\
\text { in a residential } \\
\text { state school for } \\
\text { deaf and hard of } \\
\text { hearing students. } \\
\text { Ages range from } \\
7 \text { years, } 3 \text { months } \\
\text { to } 11 \text { years, } 4 \\
\text { months. } \\
5 \text { students had } \\
\text { deaf parents and } \\
5 \text { students had } \\
\text { hearing parents. } \\
4 \text { students had } \\
\text { profound losses } \\
\text { bilaterally; } \\
5 \text { students } \\
\text { had severe to } \\
\text { profound losses } \\
\text { bilaterally; } \\
\text { and one had } \\
\text { a moderate } \\
\text { to severe loss } \\
\text { bilaterally. }\end{array}$ & $\begin{array}{l}\text { The think-aloud } \\
\text { method can be } \\
\text { used to identify } \\
\text { the metacognitive } \\
\text { reading strategies of } \\
\text { readers. } \\
\text { It was found that d/ } \\
\text { Deaf and hard of } \\
\text { hearing readers used } \\
\text { strategies within } \\
\text { three overarching } \\
\text { categories; however } \\
\text { they engaged in a } \\
\text { greater variety of } \\
\text { strategies within } \\
\text { the category of } \\
\text { constructing meaning } \\
\text { (e.g., multiple } \\
\text { interpretations, } \\
\text { inferences, drawing } \\
\text { conclusions). } \\
\text { Deaf students can } \\
\text { use metacognitive } \\
\text { strategies during } \\
\text { reading, but they } \\
\text { may not be aware } \\
\text { of or recognize their } \\
\text { own strategies. }\end{array}$ & $\begin{array}{l}\text { Future } \\
\text { researchers } \\
\text { should investigate } \\
\text { the similarities } \\
\text { and differences } \\
\text { between d/Deaf } \\
\text { and hard of } \\
\text { hearing readers } \\
\text { and typical } \\
\text { hearing readers, } \\
\text { who possess } \\
\text { high-level reading } \\
\text { skills. }\end{array}$ \\
\hline $\begin{array}{l}\text { Schirmer et } \\
\text { al. (2004) } \\
\text { Note: } \\
\text { Replication of } \\
\text { the Schirmer } \\
\text { (2003) study. }\end{array}$ & $\begin{array}{l}\text { Can thinking aloud } \\
\text { during reading be used } \\
\text { to examine the reading } \\
\text { strategies of deaf } \\
\text { students? } \\
\text { Do verbal reports of } \\
\text { deaf readers reflect } \\
\text { reading strategies } \\
\text { similar to those } \\
\text { reflected by the verbal } \\
\text { reports of hearing } \\
\text { readers? }\end{array}$ & $\begin{array}{l}\text { Qualitative } \\
\text { Design } \\
\text { (verbal } \\
\text { reports and } \\
\text { protocol } \\
\text { analysis) }\end{array}$ & $\begin{array}{l}6 \mathrm{~d} / \text { Dhh students } \\
\text { with severe to } \\
\text { profound hearing } \\
\text { loss. } \\
\text { Ages range from } \\
8 \text { years, } 5 \text { months } \\
\text { to } 11 \text { years, } 8 \\
\text { months. } \\
\text { All students had } \\
\text { hearing parents. }\end{array}$ & $\begin{array}{l}\text { Results similar to } \\
\text { those of the Schirmer } \\
\text { (2003) study. } \\
\text { Most of the reading } \\
\text { strategies used by d/ } \\
\text { Dhh students were } \\
\text { in the constructing } \\
\text { meaning category. } \\
\text { Deaf students can } \\
\text { use metacognitive } \\
\text { strategies during } \\
\text { reading, but they } \\
\text { may not be aware } \\
\text { of or recognize their } \\
\text { own strategies }\end{array}$ & $\begin{array}{l}\text { There is a strong } \\
\text { need to teach } \\
\text { students about } \\
\text { the nature and } \\
\text { use of effective } \\
\text { metacognitive } \\
\text { reading strategies. } \\
\text { Future } \\
\text { researchers } \\
\text { should continue } \\
\text { to obtain a } \\
\text { rich or elegant } \\
\text { description of } \\
\text { the reader's } \\
\text { processing; } \\
\text { this will enable } \\
\text { researchers to } \\
\text { identify the } \\
\text { similarities } \\
\text { and differences } \\
\text { between hearing } \\
\text { skilled readers } \\
\text { and readers who } \\
\text { struggle with } \\
\text { reading. }\end{array}$ \\
\hline
\end{tabular}


Table 2. Continued

\begin{tabular}{|c|c|c|c|c|c|}
\hline $\begin{array}{l}\text { Alsalem } \\
\text { (2018) } \\
\text { Note: } \\
\text { Research on } \\
\text { Arabic d/Dhh } \\
\text { students and } \\
\text { reading skills. }\end{array}$ & $\begin{array}{l}\text { Is there a difference } \\
\text { in the reading } \\
\text { comprehension } \\
\text { scores of d/Dhh } \\
\text { students when } \\
\text { using metacognitive } \\
\text { strategies through } \\
\text { digital books compared } \\
\text { with metacognitive } \\
\text { strategies through } \\
\text { traditional textbooks? } \\
\text { To what extent are } \\
\text { digital books engaging } \\
\text { d/Dhh learners in } \\
\text { higher education } \\
\text { compared with } \\
\text { traditional textbooks? } \\
\text { What are the } \\
\text { participants' } \\
\text { perceptions regarding } \\
\text { the intervention? }\end{array}$ & $\begin{array}{l}\text { Pretest- } \\
\text { Posttest } \\
\text { Experimental } \\
\text { Design }\end{array}$ & $\begin{array}{l}36 \text { college level } \\
\mathrm{d} / \text { Dhh students, } \\
\text { age } 22 \text { to } 34 \\
\text { years; hearing } \\
\text { losses range from } \\
50 \mathrm{~dB} \text { to } 90+\mathrm{dB} \text {. }\end{array}$ & $\begin{array}{l}\text { Both groups (control } \\
\text { and treatment) } \\
\text { demonstrated } \\
\text { significant } \\
\text { improvement-- } \\
\text { albeit, the actual } \\
\text { reading and/or age } \\
\text { level comprehension } \\
\text { levels were not } \\
\text { reported. } \\
\text { The treatment } \\
\text { group showed the } \\
\text { largest improvement } \\
\text { effect in reading } \\
\text { comprehension and } \\
\text { engagement. }\end{array}$ & $\begin{array}{l}\text { The use of } \\
\text { metacognitive } \\
\text { strategies-based } \\
\text { instruction } \\
\text { improves reading } \\
\text { comprehension } \\
\text { skills. } \\
\text { It was } \\
\text { hypothesized that } \\
\text { the effects would } \\
\text { be amplified if } \\
\text { such strategies } \\
\text { were used in } \\
\text { conjunction with } \\
\text { digital books. }\end{array}$ \\
\hline $\begin{array}{l}\text { Banner \& } \\
\text { Wang (2010) }\end{array}$ & $\begin{array}{l}\text { What are the reading } \\
\text { strategies used by } \\
\text { student deaf readers } \\
\text { and adult deaf readers? }\end{array}$ & $\begin{array}{l}\text { Mixed } \\
\text { Methods } \\
\text { Design }\end{array}$ & $\begin{array}{l}11 \text { participants } \\
\text { with profound } \\
\text { hearing losses; } 6 \\
\text { d/Dhh students } \\
\text { ranging from } 16 \\
\text { to } 20 \text { years of } \\
\text { age, and } 5 \text { deaf } \\
\text { adults ranging } \\
\text { from } 27-36 \text { years } \\
\text { old. }\end{array}$ & $\begin{array}{l}\text { Skilled deaf readers, } \\
\text { students and adults, } \\
\text { are able to use } \\
\text { multiple effective } \\
\text { higher-level reading } \\
\text { strategies such } \\
\text { as constructing } \\
\text { meaning, monitoring } \\
\text { and improving } \\
\text { comprehension, } \\
\text { and evaluating } \\
\text { comprehension. } \\
\text { For skilled readers, } \\
\text { researchers } \\
\text { documented the use } \\
\text { of comprehension } \\
\text { strategies } \\
\text { recommended by the } \\
\text { National Reading } \\
\text { Panel. } \\
\text { Early accessible } \\
\text { communication with } \\
\text { family members } \\
\text { and early exposure } \\
\text { to reading may } \\
\text { contribute to readers' } \\
\text { prior knowledge, } \\
\text { reading proficiency, } \\
\text { and reading strategy } \\
\text { development. } \\
\text { Reading strategies } \\
\text { learned in one } \\
\text { written language are } \\
\text { more likely to be } \\
\text { transferred to help } \\
\text { reading in another } \\
\text { language. }\end{array}$ & $\begin{array}{l}\text { Future research } \\
\text { should focus } \\
\text { on the area of } \\
\text { metacognitive } \\
\text { instruction and } \\
\text { reading among } \\
\text { struggling d/ } \\
\text { Deaf and hard of } \\
\text { hearing students. } \\
\text { There needs } \\
\text { to be a better } \\
\text { understanding } \\
\text { of the strategies } \\
\text { used by skilled d/ } \\
\text { Dhh readers. } \\
\text { Teachers are } \\
\text { encouraged to } \\
\text { provide more } \\
\text { opportunities to } \\
\text { assist students } \\
\text { in developing } \\
\text { advanced reading } \\
\text { strategies. }\end{array}$ \\
\hline
\end{tabular}


Table 2. Continued

\begin{tabular}{|c|c|c|c|c|c|}
\hline $\begin{array}{l}\text { Borgna et al. } \\
\text { (2011). }\end{array}$ & $\begin{array}{l}\text { Studied the effects of } \\
\text { multiple manipulations } \\
\text { on learning and } \\
\text { the accuracy of } \\
\text { metacognitive } \\
\text { judgments by d/Deaf } \\
\text { and hard of hearing } \\
\text { and hearing college } \\
\text { students. }\end{array}$ & $\begin{array}{l}\text { Quantitative } \\
\text { Design }\end{array}$ & $\begin{array}{l}\text { For the } 4 \\
\text { experiments: } 20 \\
\text { d/Dhh and } 20 \\
\text { hearing students } \\
\text { participated } \\
\text { in Experiment } \\
1 \text { \& } 2 ; 42 \mathrm{~d} / \\
\text { Dhh and } 42 \\
\text { hearing students } \\
\text { participated } \\
\text { in Experiment } \\
3 \text {; and } 26 \mathrm{~d} / \\
\text { Dhh and } 26 \\
\text { hearing students } \\
\text { participated in } \\
\text { Experiment } 4 \text { (All } \\
\text { participant were } \\
\text { selected from the } \\
\text { same pool). } \\
\text { Ages and hearing } \\
\text { thresholds were } \\
\text { not reported. }\end{array}$ & $\begin{array}{l}\text { All students tended } \\
\text { to overestimate } \\
\text { their performance; } \\
\text { however, typical } \\
\text { hearing students } \\
\text { demonstrated much } \\
\text { more accurate } \\
\text { performance in } \\
\text { metacognitive } \\
\text { judgments. } \\
\text { D/deaf and hard of } \\
\text { hearing readers are } \\
\text { either less aware } \\
\text { of comprehension } \\
\text { monitoring strategies } \\
\text { or are not able to } \\
\text { utilize the strategies } \\
\text { effectively. } \\
\text { Metacognitive } \\
\text { processes underlying } \\
\text { understanding } \\
\text { and learning in } \\
\text { through the air } \\
\text { communication } \\
\text { are similar to those } \\
\text { underlying learning } \\
\text { from texts. } \\
\text { Metacognitive- } \\
\text { related methods and } \\
\text { strategies found to } \\
\text { be successful for } \\
\text { hearing students do } \\
\text { not generally achieve } \\
\text { the same outcomes } \\
\text { for d/Dhh students. }\end{array}$ & $\begin{array}{l}\text { More research } \\
\text { is needed on the } \\
\text { effectiveness of } \\
\text { metacognition } \\
\text { on content } \\
\text { scaffolding. } \\
\text { Educators and } \\
\text { investigators } \\
\text { should project } \\
\text { high expectations } \\
\text { if they want better } \\
\text { performances } \\
\text { from d/Dhh } \\
\text { students. } \\
\text { There are } \\
\text { other cognitive } \\
\text { factors critical } \\
\text { for reading } \\
\text { that impact } \\
\text { comprehension. }\end{array}$ \\
\hline $\begin{array}{l}\text { Kelly et al. } \\
(2001)\end{array}$ & $\begin{array}{l}\text { Two studies: Study } 1 \\
\text { focused on whether } \\
\text { there were any } \\
\text { potential differences } \\
\text { among d/Dhh college } \\
\text { students with different } \\
\text { reading skill levels. } \\
\text { Study } 2 \text { explored } \\
\text { the effects of a } \\
\text { metacognitive } \\
\text { training session } \\
\text { on reading } \\
\text { comprehension. }\end{array}$ & $\begin{array}{l}\text { Quantitative } \\
\text { Design }\end{array}$ & $\begin{array}{l}46 \mathrm{~d} / \text { Dhh college } \\
\text { students with } \\
\text { profound hearing } \\
\text { losses. } \\
\text { Most students } \\
\text { were between } \\
18 \text { and } 25 \text { years } \\
\text { of age; two } \\
\text { students were } 29 \\
\text { and } 35 \text { years old } \\
\text { respectively. }\end{array}$ & $\begin{array}{l}\text { Reading } \\
\text { comprehension } \\
\text { strategies that work } \\
\text { well for good readers } \\
\text { may not work as } \\
\text { well for struggling or } \\
\text { poor readers. } \\
\text { Although the need } \\
\text { for differentiation } \\
\text { is obvious, it } \\
\text { is possible that } \\
\text { differentiation of } \\
\text { methods that are } \\
\text { beneficial for good } \\
\text { readers is more } \\
\text { important than } \\
\text { encouraging the } \\
\text { adoption of other } \\
\text { approaches that } \\
\text { may or may not be } \\
\text { helpful. }\end{array}$ & $\begin{array}{l}\text { Future } \\
\text { researchers } \\
\text { should focus } \\
\text { on whether } \\
\text { students continue } \\
\text { to develop and } \\
\text { improve their } \\
\text { reading skills } \\
\text { by employing } \\
\text { comprehension } \\
\text { strategies } \\
\text { independently. } \\
\\
\text { Additional } \\
\text { research is } \\
\text { needed to } \\
\text { examine the } \\
\text { development of } \\
\text { comprehension- } \\
\text { monitoring } \\
\text { strategies in } \\
\text { students. }\end{array}$ \\
\hline
\end{tabular}


Table 2. Continued

\begin{tabular}{|c|c|c|c|c|c|}
\hline $\begin{array}{l}\text { Morrison et } \\
\text { al. }(2013)\end{array}$ & $\begin{array}{l}\text { Focused on } \\
\text { students' awareness } \\
\text { of difficulties } \\
\text { with language } \\
\text { comprehension and } \\
\text { strategies for repairing } \\
\text { comprehension } \\
\text { breakdowns associated } \\
\text { with print reading } \\
\text { and through-the-air } \\
\text { (signed or spoken) } \\
\text { communication in the } \\
\text { classroom. }\end{array}$ & $\begin{array}{l}\text { Quantitative } \\
\text { Design }\end{array}$ & $\begin{array}{l}109 \mathrm{~d} / \mathrm{Dhh} \\
\text { students and } 108 \\
\text { hearing university } \\
\text { students. } \\
\text { Ages not } \\
\text { reported; hearing } \\
\text { thresholds of d/ } \\
\text { Dhh students } \\
\text { varied, but were } \\
\text { not reported for } \\
\text { all participants. }\end{array}$ & $\begin{array}{l}\text { There is a beneficial } \\
\text { reciprocal } \\
\text { relationship between } \\
\text { through-the-air } \\
\text { comprehension and } \\
\text { print comprehension. } \\
\\
\text { Comprehension- } \\
\text { monitoring skills, } \\
\text { including repair } \\
\text { strategies, should } \\
\text { be improved in both } \\
\text { through-the-air and } \\
\text { print modes. This } \\
\text { could also improve } \\
\text { learning in both } \\
\text { contexts. }\end{array}$ & $\begin{array}{l}\text { It is critical } \\
\text { to improve } \\
\text { comprehension- } \\
\text { monitoring skills, } \\
\text { including repair } \\
\text { strategies, in both } \\
\text { through-the-air } \\
\text { and print modes. } \\
\text { In essence, } \\
\text { the reading } \\
\text { and learning } \\
\text { challenges of d/ } \\
\text { Dhh learners are } \\
\text { not constrained } \\
\text { by accessing- } \\
\text { print skills only. }\end{array}$ \\
\hline $\begin{array}{l}\text { Walton et al. } \\
\text { (2019) }\end{array}$ & $\begin{array}{l}\text { Whether the construct, } \\
\text { unskilled and unaware } \\
\text { effect, can be attributed } \\
\text { predominantly to } \\
\text { language proficiency } \\
\text { (i.e., sign language } \\
\text { or general language) } \\
\text { or, perhaps, to prior } \\
\text { knowledge and/or } \\
\text { metacognitive ability. }\end{array}$ & $\begin{array}{l}\text { Quantitative } \\
\text { Design }\end{array}$ & $\begin{array}{l}90 \mathrm{~d} / \mathrm{Dhh} \text { and } 45 \\
\text { hearing college } \\
\text { students from the } \\
\text { same university } \\
\text { participated in the } \\
\text { study. } \\
47 \text { of the d/Dhh } \\
\text { participants were } \\
\text { CI users. Ages } \\
\text { and varying } \\
\text { hearing thresholds } \\
\text { were not reported. }\end{array}$ & $\begin{array}{l}\text { Individuals who are } \\
\text { unskilled or less } \\
\text { skilled in a domain } \\
\text { may still be aware } \\
\text { of what it means to } \\
\text { be "skilled" in that } \\
\text { domain. } \\
\text { The researchers } \\
\text { contended that } \\
\text { the unskilled and } \\
\text { awareness effect } \\
\text { construct is likely } \\
\text { to be influenced by } \\
\text { participants' desire to } \\
\text { be skilled or appear } \\
\text { skilled based on their } \\
\text { self-judgments. }\end{array}$ & $\begin{array}{l}\text { d/Dhh learners } \\
\text { (or other } \\
\text { learners) are } \\
\text { likely to remain } \\
\text { unskilled and } \\
\text { unaware if they } \\
\text { are not exposed } \\
\text { to adequate } \\
\text { instruction } \\
\text { regarding the } \\
\text { robustness } \\
\text { of their } \\
\text { comprehension } \\
\text { skills. } \\
\text { Similar to the } \\
\text { recommendations } \\
\text { of other cited } \\
\text { studies, additional } \\
\text { research is } \\
\text { needed on the } \\
\text { development of } \\
\text { comprehension- } \\
\text { monitoring skills. }\end{array}$ \\
\hline $\begin{array}{l}\text { Wang et al. } \\
\text { (2018) }\end{array}$ & $\begin{array}{l}\text { What factors are } \\
\text { linked to reading } \\
\text { comprehension? } \\
\text { What are the } \\
\text { similarities and } \\
\text { differences between } \\
\text { Deaf and hearing } \\
\text { readers (i.e., with } \\
\text { respect to passage } \\
\text { comprehension, } \\
\text { phonological skills, } \\
\text { and metacognition)? }\end{array}$ & $\begin{array}{l}\text { Quantitative } \\
\text { Design }\end{array}$ & $\begin{array}{l}60 \text { Deaf (with } \\
\text { prelingual } \\
\text { profound hearing } \\
\text { losses) and } \\
\text { hearing adults } \\
\text { were divided } \\
\text { into } 4 \text { groups } \\
\text { by hearing level } \\
\text { and reading } \\
\text { performance } \\
\text { level. Each } \\
\text { group contains } 15 \\
\text { adults. } \\
\text { Ages of all } \\
\text { participants } \\
\text { ranged from } 26 \text { to } \\
61 \text { years. }\end{array}$ & $\begin{array}{l}\text { Regardless of } \\
\text { phonological skills, } \\
\text { the Deaf high- } \\
\text { achieving readers } \\
\text { performed similar } \\
\text { to hearing high- } \\
\text { achieving readers-- } \\
\text { except in the area of } \\
\text { phonology. } \\
\text { All participants' } \\
\text { performances } \\
\text { indicated that } \\
\text { metacognition and } \\
\text { phonological skills } \\
\text { are linked to reading } \\
\text { comprehension } \\
\text { skills. }\end{array}$ & $\begin{array}{l}\text { Both } \\
\text { metacognitive } \\
\text { and phonological } \\
\text { skills are } \\
\text { important for } \\
\text { the development } \\
\text { of reading } \\
\text { comprehension. }\end{array}$ \\
\hline
\end{tabular}




\section{Establishing Validity and Reliability}

In the present review, triangulation was used to ensure the validity and reliability of this qualitative metaanalysis. Triangulation is a useful tool that enables the validation of the results from different viewpoints through cross verification. There are five types of triangulation that can be used in qualitative studies: theoretical, methodological, investigator, data, and environmental. In order to determine the validity and reliability of the qualitative meta-analysis results, the current research used data, theoretical, and investigator triangulations.

Triangulation of the data includes the collection of data from various resources such as different categories of people, groups, families, and communities. The present study gathered information from various databases, including Academic Search Complete, Academic Search Premier, Education Search Complete, ERIC, and PsycINFO. Also, the data included numerous worldwide publications and authentic journals such as American Annals of the Deaf, British Journal of Educational Psychology, European Journal of Psychology of Education, Journal of Applied Research in Memory and Cognition, Journal of Deaf Studies and Deaf Education, Literacy Research and Instruction, and Reading Psychology.

Theoretical triangulation is related to the utilization of various theories or hypotheses to analyze and interpret data. As mentioned previously, information based on the National Reading Panel's recommendations (2000), social-cognitive interactive models (e.g., see discussion in Paul et al., 2013), and self regulation models (e.g., Pintrich, 2000) were used to guide the interpretation of the data. These theories included but were not limited to the topics of selfregulation, self- regulation learning model, socialcognitive interactive reading, metacognitive regulation, metacognitive knowledge, and metacognitive experience. Also, the qualitative similarity hypothesis (Paul et al., 2013) was used to guide the approach of the present review.

Triangulation based on the investigator involves the analysis of all cited studies independently by the two present authors. Agreement was reached on the inclusion of studies, development of the categories for coding and documenting the data, and on the interpretations of the findings.

The benefits of triangulation include "increasing confidence in research data, creating innovative ways of understanding a phenomenon, revealing unique findings, challenging or integrating theories, and providing a clearer understanding of the problem. These benefits largely result from the diversity and quantity of data that can be used for analysis" (Thurmond, 2001, p. 254). Furthermore, triangulation can enhance researchers' understanding of the research issues and increase their confidence in the findings of the different studies.

\section{RESULTS}

As mentioned previously, we were interested in empirical studies on metacognition and reading that have been published since Strassman's (1997) review. We begin this section by providing a brief summary of Strassman's work. Then, we provide a summary of the general findings with respect to our research question.

\section{Strassman's Work}

Strassman analyzed studies published between 1973 (one of the earliest studies) and the time of her review (Strassman, 1997) - roughly, a period of 25 years. She reported that most of the previous investigations employed one of two paradigms for collecting data on metacognition, think alouds and interviews, with the latter being the most frequently used. Strassman organized her review into three broad categories: metacognitive knowledge (i.e., knowledge about reading), metacognitive control (i.e., self regulation), and intervention research (i.e., efficacy of instruction on metacognition).

Strassman also discussed her own investigation (Strassman, 1992) on metacognitive knowledge and reported findings similar to other cited studies that she reviewed (Strassman, 1997). In the 1992 study, she interviewed adolescents, with severe to profound hearing losses, ranging in age from 14 to 19 years, inclusive. Strassman's participants equated reading with their classroom activities assigned to them by their teachers - an extremely limited view of the purpose and goal of reading. The participants also depended on the teachers as "mediators"-for example, participants typically asked for teacher's assistance when they did not understand something. Only $20 \%$ of the participants would engage in a less-disruptive, more independent strategy such as rereading.

With respect to the use of strategies, Strassman (1997) summarized studies showing that students were capable of using various metacognitive strategies and that the number of strategies increased with reading grade level. Overall, the students used fewer strategies than did typical (hearing) literacy learners. It was also reported that students utilized prior knowledge as a strategy to complete tasks and used rereading and lookback strategies (reinspection of the text).

Although it was shown that good d/Deaf and hard of hearing readers, similar to good literacy learners, exhibited adequate metacogntive control, many readers did not have adequate metacognitive control or selfregulation. That is, $d /$ Deaf and hard of hearing readers were unable to identify what they know/comprehend or don't know/comprehend; thus, they could not engage in what has been labeled comprehension- monitoring strategies. With respect to the few cited intervention studies, Strassman documented that there was some evidence that the reading performance of the participants improved during the course of the intervention, with specific attention paid to the positive effects of a curriculum called Instrumental Enrichment (IE). 


\section{Summary}

With respect to typical literacy learners, it is clear that metacognitive skills develop with age and that the development of these skills requires monitoring and continued instruction by teachers. Struggling readers, similar to beginner readers, either lack or possess inadequate knowledge of metacognition and also inadequate metacognitive control (i.e., self regulation). One lingering question is whether any continual improvement in metacognition can materialize without a concomitant improvement in English language proficiency and access skill (i.e., decoding skills).

In sum, Strassman (1997) presented three major findings on the basis of her research summary. Strassman argued that current reading instructional practices may impede the development of metacognitive knowledge and strategy in d/Deaf and hard of hearing students. She also reported that metacognitive strategybased instruction is beneficial to the students. Finally, low level reading materials and inadequate instruction may not provide the opportunity for students to develop, use, and practice critical metacognitive strategies. Strassman called for additional research on metacognition, reading, and deafness.

Has this call been heeded? We summarize the findings of investigations, published since 1997 to 2020 , with respect to our main research question. We present our analysis with respect to the chronological years of the studies in two broad categories: Elementary/ Middle School and Secondary/Post-Secondary.

\section{Elementary and Middle School}

We located five studies that investigated metacognition and reading at the elementary and middle school levels. A total of 28 students participated in these investigations. It should be noted that a welldeveloped intervention can have positive effects on the improvement of reading-related factors such as, for example, vocabulary and reading comprehension. In addition, there were some positive outcomes on comprehension monitoring in the later studies.

Via the use of a think-aloud (i.e., self-reported thinking) protocol, Schirmer (2003) examined the metacognitive reading strategies used by $\mathrm{d} /$ Deaf and hard of hearing students. Schirmer asserted that her study would add to the existing database involving other reading-related factors such as prior knowledge, word identification, sentence-level understanding, and cognitive strategies (i.e., the major interest in the present review). This researcher was interested in whether the think-aloud protocol could be used to illuminate specific reading strategies and whether these reading strategies were similar to those of the verbal reports of typical (hearing) readers.

Participants were 10 elementary level students, from 7 years, 3 months to 11 years, 4 months old, enrolled in a residential state school for $\mathrm{d} /$ Deaf and hard of hearing students. One student had a moderate to severe hearing loss whereas the others' hearing losses ranged from severe to profound. The participants were videotaped reading a short story at their reading level. After each page, the participants were asked to think aloud. The researcher and her assistant documented several patterns of thinking such as predicting, summarizing, recasting, problem solving, imaging, synthesizing, appreciating, getting the gist, and questioning. Segments were selected for further analysis, using the three overarching categories (with subcategories) proposed by previous research such as constructing meaning, monitoring and improving comprehension, and evaluating comprehension.

The results revealed that the think-aloud method can be used to identify the metacognitive reading strategies of readers. In general, the results were consistent with those reported in the previous literature regarding metacognitive strategies used by readers (e.g., the review of Strassman, 1997). It was found that $\mathrm{d} /$ Deaf and hard of hearing readers used strategies within the three overarching categories; however they engaged in a greater variety of strategies within the category of constructing meaning (e.g., multiple interpretations, inferences, drawing conclusions). The students were aware of what they did or did not understand, but they were unaware of their comprehension monitoring processes. That is, they were not able to identify the sources of their misunderstandings nor did they recognize the nature of their reading strategies. The unawareness of strategies was hypothesized to be the major reason why students did not vary the use of strategies to improve their comprehension. Interestingly, there was no strong evidence that students could reflect on factors such as the quality of writing, author's voice, etc. The researcher also stated that there were a number of strategies, reported in the literature for typical literacy learners that were not used by the students.

In a replication study, Schirmer, Bailey, and Lockman (2004) utilized the same protocol (thinkaloud) to examine the reading strategies used by $6 \mathrm{~d} /$ Deaf and hard of hearing students and to compare the results with those of the previous study (Schirmer, 2003). The participants' ages ranged from 8 years, 5 months to 11 years, 8 months, and their hearing thresholds ranged from severe to profound. The results were similar to those of the Schirmer (2003) study. Again, think-aloud seems to be a reliable method for identifying the reading strategies of students. Similar to Schirmer (2003), most of the reading strategies used by $\mathrm{d} /$ Deaf and hard of hearing students were in the constructing meaning category. Although the students can use metacognitive strategies, they seem to be unaware of their comprehension-monitoring processes. Both of these studies by Schirmer and colleagues indicate the need to teach students about the nature and use of effective reading strategies.

Aceti and Wang (2010) measured the effects of an explicit approach to multi-meaning word instruction for 4 middle-school d/Deaf students, aged 11 to 13 years, with severe language delays (hearing thresholds were not reported). The researchers provided 
direct instruction on multimeaning vocabulary and integrated metacognitive strategies into their eightweek intervention. There were four stages to the intervention involving metacognitive strategies: (1) creating a picture in one's head, (2) proffering a prediction, (3) identification of words that assisted the students in understanding which multimeaning word was used in a sentence, and (4) demonstrate the basis of one's understanding (e.g., self-correcting or monitoring strategies: How do you know that? Where is the multimeaning word?).

The results highlighted that the intervention was successful for the students. Positive effects were due to the illuminations of the words and meanings, a transfer of the concept of multimeaning words in reading from teacher to student, and the use of effective metacognitive strategies. All students' multimeaning word vocabulary and reading comprehension scores were improved through the use of a metacognitivebased explicit instruction. It was concluded that multimeaning word learning and reading comprehension can be facilitated via metacognitivebased explicit instruction.

In a qualitative action research study, Brigham and Hartman (2010) explored the attempts of one teacher to integrate the metacognitive skill of prediction in a middle school social studies curriculum for d/ Deaf and hard of hearing students. The participants were 5 Hispanic students, aged 12 to 13.5 years, with severe to profound hearing losses. One student had minor cerebral palsy and another had attention deficit hyperactivity disorder (ADHD) and Goldenbar syndrome.

Both the teacher and researchers collected data through direct observations before and during the metacognitive skill-based intervention. Four strategies were integrated into the intervention such as using a timeline (i.e., a visual prompt), teaching the meaning of prediction in a constructivist manner, repeatedly reviewing the concept of prediction in multiple contexts, and having students compare the situations in their own lives with the ones in the historical events they were learning about. After participating in the intervention, all students demonstrated some understanding of the concept of prediction and exhibit some ability to make predictions. Although students attained a certain level of prediction ability, they were unable to explain the reasons for their predictions. This finding is in line with that from the work of Schirmer and the review of Strassman, discussed previously.

Benedict, Rivera, and Antia (2015) explored the effects of one broad strategy, labeled the "Comprehension, Check, and Repair Strategy" (CC\&R). Participants were three teacher-student dyads within a single-subject multiple baseline design. The student participants, 9.2 to 10.9 years old with bilateral hearing losses of varying degrees (e.g., moderate to profound), received one-on-one 4.5 to 6 weeks intervention in the areas of reading, writing, and vocabulary at least two hours a week. Various assessment methods were used to examine students' reading behavior and reading comprehension, which included a functional behavior assessment (FBA), interviews, and observations.

In the CC\&R strategy, students are taught to engage in a self-questioning technique, which is one major comprehension technique recommended by the National Reading Panel. Self-questioning can also be used for other reading-related tasks such as learning and understanding vocabulary words as was the case in our discussion of a previous study (e.g., Aceti \& Wang, 2010).

In the CC\&R model, teachers modeled the strategy and made it explicit via their own thinkaloud procedure. Teachers scaffolded the students' learning via the provision of opportunities for practice, removing prompts, and so on, until the student could perform the task independently. Benedict et al. (p. 4) provided an example of the model as seen below.

\section{The CC\&R Strategy}

1. At the end of each segment of text, the reader asks aloud, "Do I understand what I just read?"

2. If the answer is yes, the reader

- "thinks-aloud" a comment about the text

- selects an "I knew that" or an "I didn't know that" sticky note

- records the comment on the sticky note

- places the sticky note next to the appropriate segment of text

- resumes reading aloud

3. If the answer is no, the reader

- "thinks-aloud" a question about the text

- selects an "I wonder" sticky note

- records the question on the sticky note

- places the sticky note next to the appropriate segment of text

4. Before resuming reading, the reader

- determines where the answer to the question might be found

- selects a Question-Answer Response (QAR) card, and if necessary a text connection card

- resumes reading

5. Before resuming reading, the reader

- verbalizes the answer

- records the answer on the corresponding sticky note

- moves the sticky note from the place in the text where the question was asked, to the place in the text where the answer was found - resumes reading aloud

The findings of the Benedict et al. study revealed that the three students were able to increase/ improve their use of effective strategies for monitoring their comprehension. It should be highlighted that this procedure is similar to a comprehension-monitoring approach, recommended by the National Reading Panel (2000): (1) identify the location of the difficulty, (2) identify the nature of the difficulty, (3) paraphrase 
the difficulty in one's own words, (4) use a lookback technique as one approach to solve the difficulty, or (5) look ahead as an approach to solve the difficulty.

\section{Secondary and Postsecondary Levels}

Six studies explored metacognition with $\mathrm{d} /$ Deaf and hard of hearing students at the secondary and postsecondary school levels. A total of 685 students (d/ Dhh and hearing) participated in these investigations involving metacognition and English. We also included one additional study, not involving English reading, because of its focus on digital literacy, which might be promising for the development of reading-related skills (participants in this study are not part of the total of 685). It should be highlighted that interventions may have a limited effect if the content is not well developed - that is, suited to the individual needs of students. In addition, we have obtained a deeper understanding of the reading challenges of students, including the need for developing decoding skills as well as metacognitive skills such as comprehensionmonitoring and inferencing.

Kelly, Albertini, and Shannon (2001) conducted two studies involving 46 deaf college students with profound hearing losses; 20 students participated in Study 1 and 26 students in Study 2. All students were enrolled in developmental English courses based on their performances on a standardized reading test. Most students were between 18 and 25 years of age; two students were 29 and 35 years old, respectively.

Regardless of reading level, participants in the first study performed poorly on metacognitive tasks such as "recognizing incongruent content, identifying the main idea, and recalling key content information" (p. 390). Similar to what we have discussed previously, the participants tend to overestimate their reading comprehension ability. It was hypothesized that the participants were focused on reading words only, rather than on understanding the meaning of the passage. This focus may have affected their ability to perform metacognitive tasks (e.g., identifying the main idea, etc.).

In the second study, the focus was on instruction of specific reading strategies to determine if this would affect the participants' reading comprehension with respect to the tasks used in the first study. Students in the two experimental groups were compared to a control group. The experimental groups received instruction on five reading strategies as follows:

1. Know (What doI know about this? Background knowledge?)

2. Vocabulary (use glossary or dictionary, figure out meaning of word from context)

3. What do I want to know?

4. Read, reread article

5. What did I learn? (represent with a cognitive map, outline, or written summary)

Results indicated a positive effect on the better readers' retrieval of content, but not on their ability to synthesize or select the main idea. In general, the intervention on reading strategies did not significantly improve the performance of the participants. It was reported that some of the strategies of the better readers were inadequate-indicating that instruction was not effective overall for this group. It is also possible that the participants had been exposed to inaccurate classroom instruction on obtaining the main idea (i.e., read the first or last sentence), and this contributed to the results (a point also implied by Strassman, 1997). The higher readers did recall more content than did the lower or poorer readers.

The researchers concluded that the reading comprehension strategies that are successful for good readers may not be as effective for poor or struggling readers. Although it is clear that differentiation is needed, it might be that there needs to be a differentiation of strategies that are effective for good readers rather than encouraging the use of other different strategies that may not be effective. In any case, as mentioned previously, additional attention should be paid to developing comprehension-monitoring strategies in students. In our view, the general monitoring strategies of the National Reading Panel (2000) is a feasible place to start.

In their study, Banner and Wang (2010) argued that reading strategies play a significant role in the development of reading and metacognition. Good readers are distinguished by their ability to engage in "constructing meaning", "monitoring and improving comprehension" and "evaluating comprehension". Many research studies have demonstrated that metacognitive skill and reading comprehension skill have a positive and interdependent relationship. Banner and Wang (2010) suggested that future researchers should examine skilled d/Deaf and hard of hearing reader's strategies in order to generate more effective reading strategies for struggling readers.

Banner and Wang attempted to identify and examine effective metacognitive strategies in their study. Using interviews and think-aloud methods, the researchers compared adult readers to student readers. There were a total of 11 participants with a profound hearing loss $(85 \mathrm{~dB}+)-5$ deaf adults (27-36 years old) and 6 deaf students (16-20 years old). The most effective readers were those who used higher-level strategies such as constructing meaning, monitoring and improving comprehension, and evaluating comprehension. Banner and Wang documented that skilled readers were not only capable of using effective strategies, but they also used multiple strategies. In addition, the researchers documented the use of strategies such as self-generated questions, summarizing or paraphrasing, and the construction of explanations from prior knowledge-these comprehension strategies were also recommended by the National Reading Panel (2000). In essence, the researchers called for further research on proficient readers to obtain a better understanding of effective strategies that could become the focus of instruction for struggling $\mathrm{d} /$ Deaf and hard of hearing readers. 
In essence, there is a need to mitigate the situation of passive reading and problem solving by struggling literacy learners.

Borgnaetal.(2011)conducted four experiments to study the effects of multiple manipulations on learning and the accuracy of metacognitive judgments by $d /$ Deaf and hard of hearing and hearing college students (ages and hearing thresholds were not reported). A total of 216 students participated in these experiments (drawn from the same pool of participants). Although this study was not specifically on English reading or reading-related outcomes, it was motivated, in part, by the research of Marschark et al. (2009), who, according to Borgna et al., "argued that the available evidence indicates that the challenges observed in DHH students' reading are not really about reading per se" (p. 79). The implication is that there are other cognitive factors critical for reading that impact comprehension (e.g., application of prior knowledge, cognitive skills/processes, etc.). Specifically, the researchers were interested in the general finding from previous studies that documented learners' inadequate or lack of comprehension-monitoring skills. Thus, these researchers examined the learning of information from printed texts and from classroom lectures.

Our discussion here focuses on implications for the improvement of reading comprehension. For example, the researchers found that all students had the inclination to overestimate their performance; however, typical hearing students demonstrated much more accurate performance than $\mathrm{d} /$ Deaf and hard of hearing students in metacognitive judgments. Metacognitive-related methods and strategies found to be successful for hearing students do not generally achieve the same outcomes for $\mathrm{d} /$ Deaf and hard of hearing students. It was argued that the improvement of reading - and even broader learning--is contingent on the improvement of cognitive and metacognitive skills, which should support language comprehension. Similar to the findings of other studies, these researchers found that $\mathrm{d} /$ Deaf and hard of hearing readers are either less aware of comprehension-monitoring strategies or are not able to utilize the strategies effectively. Again, there is a need to focus on instruction of strategies as indicated in previous research, for example, the work of Benedict et al. (2015).

Relative to the focus of the present study, Morrison et al. (2013) reported similar and related findings. These researchers studied the performance of 109 deaf students and 108 hearing university students (ages not reported; hearing thresholds of d/Dhh students varied, but were not reported for all participants). The focus was on the students' awareness of difficulties related to language comprehension and strategies for repairing comprehension breakdowns associated with print reading and through-the-air (signed or spoken) communication in the classroom. Similar to Borgna et al. (2011), the hearing students demonstrated a greater accuracy in predictions of learning in both modalities. Again, this finding emphasizes that the reading and learning challenges of $\mathrm{d} /$ Deaf and hard of hearing learners are not constrained by accessing-print skills (e.g., decoding, etc.). In addition, as indicated by Paul and Wang (2012), there is a facilitative reciprocal relation between through-the-air comprehension and print comprehension (assuming that there are no major access issues). That is, it is important to improve comprehension-monitoring skills, including repair strategies, in both through-the-air and print modes. This might improve learning in both contexts as well.

Wang et al. (2018) examined selected factors related to reading comprehension and compared the reading processes of high- and low-Deaf adult reading achievers and high- and low-hearing adult reading achievers (ages of all participants range from 26 to 61 years). The Deaf participants had prelingual profound hearing losses $(85 \mathrm{~dB}+)$, and American Sign Language was their primary mode of communication. The hearing adults were monolingual English speakers only.

There were 60 participants; 15 in each of the four categories: high-achieving Deaf, low-achieving Deaf, high-achieving hearing, and low-achieving hearing. The researchers employed several measurements, for example, reading comprehension, phonological skills, and metacognition. The metacognitive tasks included an inferencing measure, and there was a think-aloud discussion related to the use of reading strategies.

The results indicated that both metacognition and phonological skills are related to reading comprehension skills for all groups. The performance of high-achieving Deaf participants was similar to high-achieving hearing participants, except in the area of phonology. In fact, both groups of Deaf participants performed inferior to the hearing participants in phonological processing skills. The results of the think-aloud discussion were not significant; however, on the "making inferences" measure, the hearing readers performed significantly better than the Deaf readers. Interestingly, this study supported the strong relationship of phonological processes to reading comprehension. Thus, although this study supported the findings of previous research relating to comprehension-monitoring/metacognitive strategies (e.g., Borgna et al., 2011; Morrison et al., 2013), the researchers asserted that their results "support the use of varied instruction explicitly teaching both phonological and metacognitive skills to children who are deaf or hard of hearing" (p. 459).

Walton et al. (2019) examined the ability of $d$ /Deaf and hard of hearing learners to estimate their skill on nonlinguistic (drawing) and linguistic (writing, signing) tasks (no hearing threshold levels were reported). Previous studies, some of which have been cited in the present article, have documented the relatively weak comprehension or other monitoring skills of $\mathrm{d} /$ Deaf and hard of hearing learners. Walton et al. explored the construct, unskilled and unaware effect, and whether this construct can be attributed predominantly to language proficiency (i.e., sign language or general language) or, perhaps, to prior knowledge and/or metacognitive ability. 
$90 \mathrm{~d} /$ Deaf and hard of hearing and 45 hearing college students from the same university participated in the study (ages and varying hearing thresholds were not reported). 47 of the $\mathrm{d} / \mathrm{Dhh}$ participants were Cochlear Implant users. Participants were involved in completing tasks such as drawing, writing, ASL, and signed English - and rating their performances (i.e., their skill levels).

Results indicated no group differences on ratings of drawing skills. It was no surprise that the hearing participants performed better on writing whereas the $\mathrm{d} / \mathrm{Dhh}$ participants demonstrated better sign skills in ASL and signed English. With respect to skill awareness, there was no difference between the groups for drawing skills; however, $\mathrm{d} / \mathrm{Dhh}$ participants overestimated their skills whereas hearing participants underestimated their skills. With respect to writing, hearing participants underestimated their writing skills while $\mathrm{d} / \mathrm{Dhh}$ participants overestimated their writing skills. Thus, these results reiterated early findings that the $\mathrm{d} / \mathrm{Dhh}$ participants are less aware of their skill levels than their hearing counterparts.

With respect to the sign tasks (ASL and signed English), both groups overestimated their ASL skill levels whereas the $\mathrm{d} /$ Dhh participants underestimated their sign English skills even though they performed better than the hearing participants on all sign tasks. The researchers interpreted the signing results in this manner: the $\mathrm{d} / \mathrm{Dhh}$ participants were skilled but unaware.

It is interesting to note that even if individuals are unskilled or, perhaps, less skilled in a domain, they may still be able to be aware of what it means to be "skilled" in that domain. In addition, the researchers argued that the unskilled and awareness construct is likely to be influenced by participants' desire to either be skilled or appear to be skilled via their self-judgments. Clearly, if $\mathrm{d} / \mathrm{Dhh}$ learners (or other learners) are not in a position to be exposed to adequate instruction regarding the robustness of their comprehension skills, they are likely to remain unskilled and unaware. Similar to other previous studies, more attention needs to be paid to the development of comprehension- monitoring skills - not only to print literacy skills. In fact, these researchers reiterated a previous argument (Marschark and his colleagues) that $\mathrm{d} / \mathrm{Dhh}$ students' reading challenges are not due to print literacy challenges. As we mentioned earlier, we would qualify this by stating that the reading challenges are not "solely" due to print literacy challenges if print literacy skills are restricted to decoding and language skills. In other words, "reading" for us, especially within the framework of the QSH (Paul et al., 2013) involves more than just "print literacy skills".

\section{Other Related Studies}

As mentioned previously, there have been other studies on the metacognitive abilities of elementary and secondary-age d/Deaf and hard of hearing students in languages other than English, most notably, Arabic (e.g., Al-Hilawani, 2000, 2001, 2008, 2017). We highlight a study here (Alsalem, 2018) that focused on metacognition and Arabic reading skills with college students because of the use of digital media, which seems to be an interesting avenue for the development of comprehension skills.

Alsalem (2018) explored the effects of digital books with metacognitive strategies on the reading comprehension skills of $\mathrm{d} /$ Deaf and hard of hearing students in higher education in Saudi Arabia. Also of interest were the effects on the engagement level of students and their perspectives regarding the intervention (i.e., social validity). Digital books (aka electronic or e-books) are considered to be a form of digital literacy in which, for example, students can interact with the text via the use of pictures, graphics, hyperlinking, and 3-D modeling.

Participants included two groups of $36 \mathrm{~d} /$ Deaf and hard of hearing university students between the ages of 22 and 34 years. The hearing levels of the students ranged from $50 \mathrm{~dB}$ to $90 \mathrm{~dB}+$; students used either Arabic sign language or spoken language as their primary communication method. The students were assigned to either a control or treatment group as part of an experimental pre- and post-test design. Measures included a standardized reading comprehension measure, classroom observations for assessing engagement and treatment fidelity, and an assessment of the perspectives of students (social validity).

Both groups were exposed to similar reading materials and similar metacognitive strategies such as inferring meaning through word analysis, using prior knowledge, and comprehension monitoring and repair strategies. The control group received instruction via the use of print books whereas the treatment group used the digital books within a 4-month intervention timeframe. It was argued that the digital books provided opportunities for the treatment group to interact with the content at their own pace and convenience. Thus, this group had more control over their interactions with the text. It was suspected that the use of digital books would simulate a real classroom by providing immediate feedback, which should increase motivation, interest, and engagement.

Based on the pre- and post-test measures, both groups demonstrated significant improvement - albeit, the actual reading and/or age level comprehension levels were not reported. Nevertheless, the treatment group exhibited the largest effect in both reading comprehension and engagement. The common finding was that the use of metacognitive strategiesbased instruction has a positive effect on reading comprehension skill. Nevertheless, the author hypothesized that the effects would be greater if such strategies are employed with the use of digital books. This is an area for future investigations. 


\section{CONCLUSION}

The present narrative review attempted to provide a summary of the empirical findings on metacognition and English-reading related tasks since the last and only published review by Strassman (1997). In general, there is evidence that $\mathrm{d} /$ Deaf and hard of hearing literacy learners demonstrated improvement in their reading comprehension, metacognitive knowledge, and self-regulation (e.g., Aceti \& Wang, 2010; Benedict et al, 2005; Schirmer, 2003; Schirmer et al, 2004; Wang et al., 2018). A few of the cited studies illustrated that the students may benefit from metacognitive strategybased instruction and explicit teaching (Aceti \& Wang, 2010, Brigham \& Hartman, 2010). However, one study found that interventions might not have the desired effect unless they are specifically tailored to the individual needs of the students (Kelly et al., 2001). It does not seem to be effective to identify successful strategies of good literacy learners and teach those strategies without differentiation to struggling literacy learners.

Most of the studies cited in the present review repeatedly documented that $\mathrm{d} /$ Deaf and hard of hearing literacy learners have insufficient knowledge of comprehension-monitoring and other effective metacognitive skills. In essence, these learners tend to overestimate their ability and do not know "what they do not know." Nearly all of the studies have reiterated a major recommendation proffered by the Strassman's (1997) review - the need to improve comprehensionmonitoring skills.

The work of Marschark and his colleagues (Borgna et al., 2011; Marschark et al., 2009; Morrison et al., 2013; Walton et al., 2019) provided additional perspectives on the role of metacognition (as part of the executive function) on reading and learning. These scholars asserted that the reading (and learning) problems of $\mathrm{d} / \mathrm{Dhh}$ learners are not specifically due to "reading." The assumption is that inadequate higher-level executive functions or metacognitive skills contribute to these reading challenges. Several factors were suggested to support this assumption, for example, small and unconnected vocabulary knowledge in long-term memory resulting in an impoverished development and use of prior knowledge, particularly during reading tasks (also see Marschark \& Knoors, 2012; Trezek et al., 2011). Because language competency or fluency is critical for the development of the executive function, it is clear that poor language skills impede the acquisition of effective cognitive skills. In fact, it has been argued that delays in language development reflect delays in executive functioning. Individuals with limited prior or background knowledge do not realize how much they do not know or comprehend, and they are inclined to overestimate their performance or skill level.
In essence, Marschark and his colleagues argued that the reading problems of $d /$ Deaf and hard of hearing individuals are not due solely to reading - if reading is defined as accessing print.

In our view, this does not diminish the importance of accessing print; however, it is clear that reading is much more than language comprehension and decoding skills. We argue that reading is a cognitive skill supported by language and prior knowledge, at the least.

The limitations of the present review should be acknowledged. Although we included empirical articles that were published in peer-reviewed journals and met our inclusion criteria, we did not conduct an evaluation of the quality indicators of these studies. This is a recommendation for future researchers. Despite our search efforts, it is possible that we neglected to include or overlooked a few relevant studies. We also acknowledge that our findings are open to varying interpretations - albeit, we believed that we have been comprehensive and balanced in our rendition.

We have a few recommendations for future research. There is a need to conduct investigations with a larger sample size and to recruit individuals with varying ages, hearing loss levels, and educational backgrounds. We recommend strongly that adequate sociodemographics be reported (e.g., hearing threshold levels, ages, etc.). In addition, multiple readability formulas should be used to select the most readable texts for d/Deaf and hard of hearing students so that focus can be on assessing metacognitive ability. Alternative measurements should be addressed and considered in examining the students' reading comprehension levels. Various data collection methods should be used to investigate metacognitive skills-albeit think alouds and interviews seem to be most effective. Future researchers should continue to examine skilled d/Deaf and hard of hearing readers' strategies and recommend more effective reading strategies for struggling $\mathrm{d} /$ Deaf and hard of hearing readers. Last but not least, future researchers should investigate the benefits of digital literacy and the interrelations of metacognition, prior knowledge, decoding skills, and motivational variables.

In sum, it is clear that metacognitive skills contribute significantly to the development of English reading comprehension skills for d/ Deaf and hard of hearing students. We emphasize, however, that these are not the only skills necessary for the development of reading, especially if reading acquisition is contextualized with respect to extant English literacy theories. It is critical to improve comprehension-monitoring abilities of the students, but not at the expense of neglecting the development and improvement of overall English language comprehension and print-access skills. 


\section{REFERENCES}

* Studies analyzed in this article.

*Aceti, K. J., \& Wang, Y. (2010). The teaching and learning of multimeaning words within a metacognitively based curriculum. American Annals of the Deaf, 155(2), 118-123.

Alasim, K. (2020). Understanding factors that affect the prior knowledge of deaf and hard of hearing students and their relation to reading comprehension. Deafness \& Education International, 22(3), 232-250.

Al-Hilawani, Y. A. (2000). A new approach to evaluating metacognition in hearing average-achieving, hearing underachieving, and deaf/hard-of-hearing elementary school students. British Journal of Special Education, 27(1), 41-47.

Al-Hilawani, Y. A. (2001). Examining metacognition in hearing and deaf/hard of hearing students: A comparative study. American Annals of the Deaf, 146(1), 45-50.

Al-Hilawani, Y. A. (2008). Metacognitive performances of hearing students and of students who are deaf and hard-ofhearing on two types of measures: Visual-voiced and visual-visual stimuli. International Journal of Disability, Development and Education, 55(4), 331-339.

Al-Hilawani, Y. A. (2017). Hearing and deaf and hard of hearing: A comparison on metacognition, the Mooney Problem Checklist, IQ, and gender. Volta Review, 116(1-2), 5-28.

Allen, T. (1986). Patterns of academic achievement among hearing impaired students: 1974 and 1983. In A. Schildroth \& M. Karchmer (Eds.), Deaf children in America (pp. 161206). Little, Brown.

*Alsalem, M. A. (2018). Exploring metacognitive strategies utilizing digital books: Enhancing reading comprehension among deaf and hard of hearing students in Saudi Arabian higher education settings. Journal of Educational Computing Research, 56(5), 645-674.

Alvermann, D. E., Unrau, N. J., \& Ruddell, R. B. (Eds.). (2013). Theoretical models and processes of reading $\left(6^{\text {th }} \mathrm{ed}\right.$.). International Reading Association.

Archbold, S. (2010). Deaf education: Changed by cochlear implantation? Nijmegen, The Netherlands: University of Nijmegen Medical Centre.

Baker, L., \& Beall, L. S. (2009). Metacognitive processes and reading comprehension. In S. Israel \& G. Duffy (Eds.), Handbook of research on reading comprehension (pp. 373-388). Routledge.

Baker, L., \& Brown, A. (1984). Metacognitive skills and reading. In P. D. Pearson, R. Barr, M. Kamil, \& P. Mosenthal (Eds.), Handbook of reading research (pp. 353-394). Longman.

*Banner, A., \& Wang , Y. (2010). An analysis of the reading strategies used by adult and student deaf readers. Journal of Deaf Studies and Deaf Education, 16(1), 2-23.

*Benedict, K. M., Rivera, M. C., \& Antia, S. D. (2015). Instruction in metacognitive strategies to increase deaf and hard of hearing students' reading comprehension. Journal of Deaf Studies and Deaf Education, 20(1), 1-15.

*Borgna, G., Convertino, C., Marschark, M., Morrison, C., \& Rizzolo, K. (2011). Enhancing deaf students' learning from sign language and text: Metacognition, modality, and the effectiveness of content scaffolding. Journal of Deaf Studies and Deaf Education, 16(1), 79-100.

*Brigham, M., \& Hartman, M. C. (2010). What is your prediction? Teaching the metacognitive skill of prediction to a class of sixth and seventh grade students who are deaf. American Annals of the Deaf, 155(2), 137-143.

Brigham, R., Berkeley, S., Simpkins, P., \& Brigham, M. (2007). Reading comprehension strategy instruction. Current Practice Alerts, 12. Retrieved from http://TeachingLD.org/alerts.

Brown, A. (1975). The development of memory: Knowing, knowing about knowing, and knowing how to know. Advances in Child Development and Behavior, 10, 103151
Connor, C. M., Alberto, P. A., Compton, D. L., \& O'Connor, R. E. (2014). Improving reading outcomes for students with or at risk for reading disabilities: A synthesis of the contributions from the Institute of Education Sciences Research Centers (NCSER 2014-3000). Washington, DC: National Center for Special Education Research, Institute of Education Sciences, U.S. Department of Education.

Courtin, C., \& Melot, A.-M. (2005). Metacognitive development of deaf children: Lessons from the appearance-reality and false belief tasks. Developmental Science, 8(1), 16-25.

Easterbrooks, S. R., \& Beal-Alvarez, J. (2012). States' reading outcomes of students who are d/Deaf and hard of hearing. American Annals of the Deaf, 157(1), 27-40.

Franklin, S. V., Hane, E., Kustusch, M. B., Ptak, C., \& Sayre, E. C. (2018). Improving retention through metacognition: A program for deaf/hard-of-hearing and first generation STEM college students. Journal of College Science Teaching, 48(2), 21-27.

Hirsch, E. D., Kett, J., \& Trefil, J. (Eds). (2002). The new dictionary of cultural literacy (3rd ed.). Houghton Mifflin.

Ingraham, C. L., \& Andrews, J. F. (2010). The hands and reading: What deafblind adult readers tell us. British Journal of Visual Impairment, 28(2), 130-138.

*Kelly, R. R., Albertini, J. A., \& Shannon, N. B. (2001). Deaf college students' reading comprehension and strategy use. American Annals of the Deaf, 146(5), 385-400.

Kyle, F. E., \& Cain, K. (2015). A comparison of deaf and hearing children's reading comprehension profiles. Topics in Language Disorders, 35(2), 144-156.

Luckner, J., \& Handley, C. (2008). A summary of the reading comprehension research undertaken with students who are deaf or hard of hearing. American Annals of the Deaf, 153(1), 6-36.

Marschark, M., \& Knoors, H. (2012). Educating deaf children: Language, cognition, and learning. Deafness and Education International, 14(3), 136-160.

Marschark, M., Sapere, P., Convertino, C., Mayer, C., Wauters, L., \& Sarchet, T. (2009). Are deaf students' reading challenges really about reading? American Annals of the Deaf, 154, 357-370.

Martin, D. S., Craft, A., \& Sheng, Z. N. (2001). The impact of cognitive strategy instruction on deaf learners: An international comparative study. American Annals of the Deaf, 146(4), 366-378.

Massey, D. D. (2009). Self-regulated comprehension. In S. Israel \& G. Duffy (Eds.), Handbook of research on reading comprehension (pp. 389-399). Routledge.

Mayer, C., \& Leigh, G. (2010). The changing context for sign bilingual education programs: Issues in language and the development of literacy. International Journal of Bilingual Education and Bilingualism, 13(2), 175-186.

Mayer, C., \& Trezek, B. J. (2015). Early literacy development in deaf children. Oxford University Press.

Mayer, C., \& Trezek, B. J. (2018). Literacy outcomes in deaf students with cochlear implants: Current state of the knowledge. Journal of Deaf Studies and Deaf Education, 23(1), 1-16.

Moores, D. F. (2001). Educating the deaf: Psychology, principles, and practices (5th ed.). Houghton-Mifflin.

*Morrison, C., Marschark, M., Sarchet, T., Convertino, C. M., Borgna, G., \& Dirmyer, R. (2013). Deaf students' metacognitive awareness during language comprehension. European Journal of Special Needs Education, 28(1), 78-90.

National Reading Panel. (2000). Report of the National Reading Panel: Teaching children to read - An evidence-based assessment of the scientific research literature on reading and its implications for reading instruction. Jessup, MD: National Institute for Literacy at EDPubs. 
Paul, P. V. (2009). Language and deafness (4 ${ }^{\text {th }}$ ed.). Jason \& Bartlett.

Paul, P. V., \& Wang, Y. (2012). Literate thought:Understanding comprehension and literacy. Jason \& Bartlett Learning.

Paul, P. V., Wang, Y., \& Williams, C. (2013). Deaf students and the qualitative similarity hypothesis: Understanding language and literacy development. Gallaudet University Press.

Pintrich, P. R. (2000). The role of goal orientation in self-regulated learning. In M. Boekaerts, P. Pintrich, \& M. Zeidner (Eds.), Handbook of self-regulation (pp.452-502). Academic Press.

Qi, S., \& Mitchell, R. E. (2012). Large scale academic achievement testing of deaf and hard-of-hearing students: Past, present, and future. Journal of Deaf Studies and Deaf Education, 17, 1-18.

*Schirmer, B. R. (2003). Using verbal protocols to identify the reading strategies of students who are Deaf. Journal of Deaf Studies and Deaf Education, 8(2), 157-70.

*Schirmer, B. R., Bailey, J., \& Lockman, A. S. (2004). What verbal protocols reveal about the reading strategies of deaf students: A replication study. American Annals of the Deaf, 149(1), 5-16.

Strassman, B. K. (1992). Deaf adolescents' metacognitive knowledge about school-related reading. American Annals of the Deaf, 137, 326-330.

*Strassman, B. K. (1997). Metacognition and reading in children who are deaf: A review of the research. Journal of Deaf Studies \& Deaf Education, 2(3), 140-149.
Thurmond, V. A. (2001). The point of triangulation. Journal of Nursing Scholarship, 33(3), 253-258.

Timulak, L. (2007). Identifying core categories of client identified impact of helpful events in psychotherapy: A qualitative meta-analysis. Psychotherapy Research, 17, 305-314.

Trezek, B. J., Wang, Y., \& Paul, P. V. (2011). Processes and components of reading. In M. Marschark \& P. Spencer (Eds.), Handbook of deaf studies, language, and education (Vol. 1; $2^{\text {nd }}$ ed.) (pp. 99-114). Oxford University Press.

*Walton, D., Borgna, G., Marschark, M., Crowe, K., \& Trussell, J. (2019). I am not unskilled and unaware: Deaf and hearing learners' self-assessments of linguistic and nonlinguistic skills. European Journal of Special Needs Education, 34(1), 20-34.

*Wang, Y., Silvestri, J. A., \& Jahromi, L. B. (2018). Selected factors in reading comprehension for deaf and hearing adults: Phonological skills and metacognition. American Annals of the Deaf, 162(5), 445-462.

Wang, Y., \& Williams, C. (2014). Are we hammering square pegs into round holes? An investigation on the meta-analyses of reading research with students who are d/Deaf or hard of hearing and students who are hearing. American Annals of the Deaf, 159(4), 323-345.

Yuknis, C. (2014). A grounded theory of text revision processes used by young adolescents who are deaf. Exceptional Children, 80(3), 307-322. 